\title{
Pelaksanaan Model Pembelajaran Student Team Achievement Division (STAD) Dan Pemanfaatan Sumber Belajar Terhadap Hasil Belajar Siswa Program Keahlian Teknik Instalasi Tenaga Listrik
}

\author{
Retyana Wahrini ${ }^{1}$, Labusab ${ }^{2}$, E.Makmur ${ }^{3}$ \\ Pendidikan Vokasional Mekatronika, Universitas Negeri Makassar \\ Makassar, Sulawesi Selatan \\ ${ }^{1}$ retyana.wahrini@unm.ac.id, ${ }^{2}$ ochalabusab@unm.ac.id, ${ }^{3}$ elfiramakmur@unm.ac.id
}

\begin{abstract}
Penelitian ini bertujuan untuk mengetahui pengaruh: (1) persepsi siswa tentang model pembelajaran kooperatif STAD terhadap hasil belajar siswa pada mata pelajaran pengendali daya tegangan rendah di SMKN 1 Sedayu Yogyakarta, (2) pemanfaatan sumber belajar terhadap hasil belajar siswa pada mata pelajaran pengendali daya tegangan rendah di SMKN 1 Sedayu Yogyakarta, dan (3) persepsi siswa tentang model pembelajaran kooperatif STAD dan pemanfaatan sumber belajar terhadap hasil belajar siswa kelas XI pada mata pelajaran pengendali daya tegangan rendah di SMKN 1 Sedayu Yogyakarta. Penelitian ini merupakan penelitian Ex-post Facto yang dilakukan di SMKN 1 Sedayu Program Keahlian TITL. Subyek dalam penelitian ini adalah siswa kelas XI Program Keahlian TITL dengan populasi sebanyak 105 siswa. Pengumpulan data dalam penelitian ini menggunakan metode angket. Analisis data menggunakan analisis regresi sederhana dan analisis regresi ganda. Validitas instrumen penelitian ini melalui expert judgement kepada dosen ahli sedangkan reliabilitas instrumen diketahui dengan rumus alpha Cronbach. Hasil penelitian menunjukkan bahwa: (1) Persepsi siswa tentang model pembelajaran kooperatif STAD tergolong sangat baik; (2) Pemanfaatan sumber belajar tergolong sangat baik; (3) Hasil belajar siswa Program Keahlian TITL di SMKN 1 Sedayu Yogyakarta yang telah mencapai nilai KKM sebanyak 40\%, dan siswa yang belum mencapai nilai KKM 60\%.; (4) Terdapat pengaruh positif dan signifikan persepsi siswa tentang model pembelajaran kooperatif STAD terhadap hasil belajar siswa ditunjukkan dengan Y= 29,798 $+0,540 \mathrm{X} 1$ dengan kontribusi sebesar 48,6\%.; (5) Terdapat pengaruh positif dan signifikan pemanfaatan sumber belajar terhadap hasil belajar siswa ditunjukkan dengan $\mathrm{Y}=41,637+0,367 \mathrm{X} 2$ dengan kontribusi sebesar 28,7\%; (6) Terdapat pengaruh yang signifikan persepsi siswa tentang model pembelajaran kooperatif STAD dan pemanfaatan sumber belajar terhadap hasil belajar siswa ditunjukkan dengan

$\mathrm{Y}=30,028+0,570 \mathrm{X} 1-0,034 \mathrm{X} 2$ dengan kontribusi sebesar 48,7\%
\end{abstract}

Keywords: STAD, Sumber Belajar, Hasil Belajar

\section{PENDAHULUAN}

\section{A. Latar Belakang}

Pembelajaran pada dasarmya merupakan bantuan yang diberikan pendidik agar dapat terjadi proses perolehan ilmu dan pengetahuan serta pembentukan sikap dan kepercayaan peserta didik. Dengan kata lain, pembelajaran adalah proses untuk membantu peserta didik agar dapat belajar dengan baik. Dalam kegiatan pembelajaran terjadi interaksi antara siswa dengan siswa, interaksi antara guru dan siswa, maupun interaksi antara siswa dengan sumber belajar. Diharapkan dengan adanya interaksi tersebut, siswa dapat membangun pengetahuan secara aktif, pembelajaran berlangsung secara interaktif, inspiratif, menyenangkan, menantang, serta dapat memotivasi peserta didik sehingga mencapai kompetensi yang diharapkan.

Dunia pendidikan tidak lepas dari persoalan-persoalan dan kesulitan-kesulitan dalam memenuhi tuntutan zaman yang semakin berkembang khususnya dibidang Pengendali Daya Tegangan Rendah. Salah satu usaha untuk mengatasi persoalanpersoalan tersebut antara lain adalah untuk mengembangkan metode pembelajaran yang efektif, serta usaha untuk menyusun organisasi pelaksanaan pembelajaran yang mantap dan mampu menjawab persoalan yang ada.

Model pembelajaran memiliki peranan yang penting dalam proses belajar mengajar. Model pembelajaran yang digunakan oleh guru dapat membantu siswa meningkatkan pemahaman dan membangkitkan motivasi siswa. Oleh karena itu, penggunaan model pembelajaran sangat dibutuhkan dalam setiap mata pelajaran, tidak terkecuali pada mata pelajaran Pengendali Daya Tegangan Rendah.

SMK Negeri 1 Sedayu Yogyakarta sebagai salah satu wadah, basis pendidikan dan keterampilan. Visi SMK Negeri 1 SEDAYU menjadikan SMK Negeri 1 Sedayu sebagai lembaga kependidikan dan pelatihan di bidang teknologi yang berwawasan luas. Misi SMK Negeri 1 SEDAYU adalah menjunjung tinggi agama dan nilai-nilai budaya, berkualitas dan profesional di bidangnya, serta mampu bersaing dalam kompetisi global.

Berdasarkan hasil survey peneliti ke SMK Negeri 1 Sedayu, guru telah menggunakan model pembelajaran kooperatif STAD pada mata pelajaran Pengendali Daya Tegangan Rendah. Pembelajaran dengan model kooperatif STAD ditujukan supaya hasil belajar siswa lebih baik dibandingkan tahun sebelumnya yang masih menggunakan metode ceramah. Hasil belajar siswa pada mata pelajaran Pengendali Daya Tegangan Rendah selama 
ini masih relatif rendah. Siswa belum memanfaatkan sumber belajar secara optimal untuk mendukung pembelajaran.

Pencapaian hasil belajar siswa SMK dipengaruhi oleh sumber belajar dan model pembelajaran inovatif yang dipakai oleh guru untuk menyampaikan materi pembelajaran di dalam kelas. Berdasarkan permasalahan di atas perlu dilakuakan penelitian pengaruh model pembelajaran STAD yang telah diterapkan dalam proses belajar mengajar di SMK Negeri 1 Sedayu dan pemanfaatan sumber belajar terhadap pencapaian hasil belajar siswa SMK Negeri 1 Sedayu Yogyakarta pada mata diklat Pengendali Daya Tegangan Rendah.

\section{LANDASAN TEORI}

Penelitian ini menggunakan teori-teori pendukung penelitian tentang Student Team Achievement Division (STAD), sumber belajar, dan hasil belajar. Landasan teori-teori tersebut adalah sebagai berikut:

A. Student Team Achievement Division (STAD)

Proses pembelajaran kooperatif tipe STAD memiliki lima tahapan meliputi : tahap penyajian materi, tahap penyajian kelompok, tahap tes individu, dan tahap pemberian penghargaan kelompok [1]. Keunggulan model pembelajaran kooperatif tipe STAD yaitu siswa dapat saling membelajarkan sesame siswa lainnya atau pembelajaran oleh rekan sebaya yang lebih efektif daripada pembelajaran oleh guru dan dapat mengurangi sifat individualistis siswa

Kelebihan dari pembelajaran kooperatif tipe STAD yaitu dapat: meningkatkan motivasi siswa dalam belajar, meningkatkan prestasi belajar siswa, meningkatkan kreatifitas siswa, mendengar, menghormati, serta menerima pendapat siswa lain, mengurangi kejenuhan dan kebosanan, meyakinkan dirinya untuk orang lain dengan membantu orang lain dan meyakinkan dirinya untuk saling memahami dan saling mengerti.

Persepsi siswa terhadap model pembelajaran kooperatif tipe STAD merupakan suatu proses yang menyangkut masuknya pesan atau informasi ke dalam otak manusia [4]. Melalui persepsi siswa terhadap model pembelajaran kooperatif tipe STAD merupakan suatu kemampuan otak dalam menerjemahkan/mengintrepetasi stimulus yang masuk ke dalam alat indera

B. Sumber Belajar

Sumber belajar merupakan salah satu komponen yang membantu dalam proses belajar mengajar. Sumber belajar tidak lain adalah daya yang dapat dimanfaatkan guna kepentingan proses belajar mengajar, baik secara langsung maupun tidak langsung, sebagian atau keseluruhan. Sumber belajar dalam pembelajaran termasuk orang (penulis buku, prosedur media, dan lain-lain), cara-cara tertentu dalam mengolah/menyajikan pesan, serta lingkungan dimana proses pendidikan itu berlangsung .

Secara tradisional, sumber belajar adalah guru dan buku paket. Padahal sumber belajar yang ada di sekitar sekolah banyak dan sangat disayangkan berbagai sumber belajar yang banyak tersebut belum bisa dimanfaatkan secara maksimal karena sumber belajar merupakan suatu unsur yang memiliki peranan penting dalam menentukan proses belajar agar pembelajaran menjadi efektif dan efisien dalam pencapaian tujuan. Dari sekian banyaknya sumber belajar hanya buku teks yang banyak dimanfaatkan. Sumber belajar sebagaimana diketahui adalah sarana atau fasilitas pendidikan yang merupakan komponen penting untuk terlaksananya proses belajar mengajar di sekolah.

Berdasarkan pendapat tentang pengertian sumber belajar di atas, maka dapat ditarik kesimpulan bahwa sumber belajar adalah segala sesuatu yang dapat dimanfaatkan guru maupun siswa dalam mempelajari materi pelajaran, sehingga dapat memudahkan siswa dalam memahami materi pelajaran tersebut yang mengorganisasikan berbagai sumber belajar ke dalam sistem pembelajaran untuk memenuhi kebutuhan belajar. Pada prinsipnya sumber belajar mencakup orang, isi, pesan, media, alat, teknik, dan latar lingkungan yang mengandung informasi yang dirancang atau dimanfaatkan untuk memfasilitasi seseorang belajar sehingga memungkinkan peserta didik untuk belajar secara mandiri.

C. Hasil Belajar

Hasil belajar ialah perubahan tinglah laku yang mencakup bidang kognitif, afektif, dan psikomotor yang dimiliki siswa setelah menerima pengalaman belajar. Hasil belajar juga merupakan sesuatu yang diperoleh dari suatu aktifitas, sedangkan belajar merupakan proses yang mengakibatkan perubahan pada individu, yakni perubahan tingkah laku, baik aspek pengetahuannya, keterampilannya, maupun aspek sikapnya . Hasil belajar yang diperoleh siswa setelah setelah proses belajar mengajar ditunjukkan dalam bentuk prestasi belajar maupun perubahan tingkah lakunya. Hasil belajar dipengaruhi oleh dua faktor, yaitu faktor intern dan ekstern. Faktor intern merupakan faktor yang ada dalam diri individu yang sedang belajar, sedangkan faktor ekstern merupakan faktor dari luar individu. Faktor intern meliputi faktor jasmaniah, faktor psikologis, dan faktor kelelahan. Faktor ekstern meliputi faktor keluarga, faktor sekolah, serat faktor masyarakat.

Hasil belajar merupakan suatu puncak proses belajar. Hasil belajar tersebut terjadi terutama berkat evaluasi guru. Hasil belajar dapat berupa dampak pengajaran dan dampak pengiring. Kedua dampak tersebut bermanfaat bagi guru dan siswa. Kesimpulan hasil belajar pada hakekatnya adalah perubahan perilaku siswa dalam bakat pengalaman dan pelatihan setekah melaui proses pembelajaran.

\section{METODE PENELITIAN}

Penelitian ini merupakan penelitian ex post facto. Keterangan-keterangan yang dihimpun adalah keterangan yang berdasarkan kejadian atau pengalaman yang telah berlangsung baik itu menyangkut persepsi siswa tentang model pembelajaran kooperatif tipe STAD yang pernah dialami oleh siswa, maupun dalam pemanfaatan sumber-sumber belajar yang tersedia untuk menunjang hasil belajar siswa. Penelitian ex post facto adalah penemuan empiris yang dilakukan secara sistematis, peneliti tidak melakukan control terhadap variabel-variabel bebas karena manifestasinya sudah terjadi atau variabel-variabel tersebut secara inheren tidak dapat dimanipulasi

A. Populasi Dan Sampel Penelitian 
Populasi dari penelitian ini adalah seluruh siswa kelas XI program studi Teknik Instalasi Tenaga Listrik SMK Negeri 1 Sedayu Yogyakarta yaitu Kelas XI TITL A, XI TITL B, XI TITL C. Jumlah populasi siswa Kelas XI program studi Teknik Instalasi Tenaga Listrik sebanyak 105 siswa.

\section{B. Teknik Pengumpulan Data}

Teknik pengumpulan data yang digunakan dalam penelitian ini adalah teknik angket atau kuesioner. Untuk megungkap data variable tentang persepsi siswa terhadap model pembelajaran kooperatif tipe STAD dan pemanfaatan sumber belajar dalam penelitian ini, digunakan instrumen berdasar Skala Likert yang sudah dimodifikasi.

\section{Variabel Penelitian Dan Paradigma Penelitian}

Variabel yang digunakan dalam penelitian ini yaitu dua variabel bebas (X1 dan X2) dan satu variabel terikat (Y). Variabel bebas pada penelitian ini yaitu Persepsi siswa tentang model pembelajaran kooperatif STAD (X1), Pemanfaatan sumber belajar (X2), variabel terikatnya yaitu Hasil belajar (Y).

Hubungan antar variabel bebas (X1 dan X2) dan variabel terikat (Y) dapat digambarkan sebagai berikut:

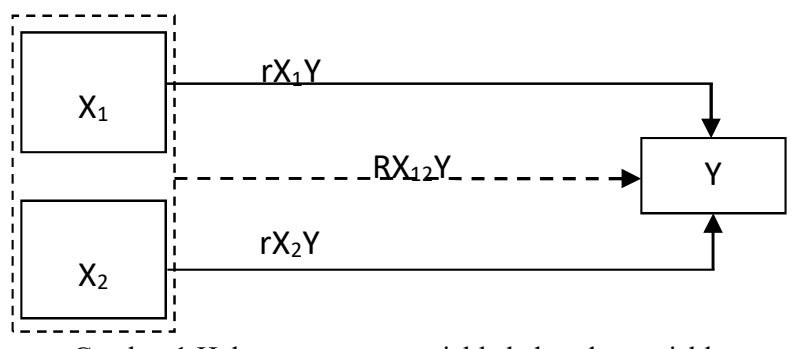

Gambar 1.Hubungan antara variable bebas dan variable terikat

\section{Validitas Instrumen}

Validitas adalah ukuran yang menunjukkan tingkattingkat kevalidan atau kesahihan suatu instrumen. Sebuah instrument dikatakan valid apabila dapat mengungkap data dari variabel yang diteliti secara tepat.

Instrumen dinyatakan valid apabila hasil perhitungan yaitu rhitung > rtabel pada $\alpha=5 \%$, dan apabila rhitung < rtabel pada $\alpha$ $=5 \%$ maka instrumen tidak valid dan tidak dapat digunakan dalam pengambilan data penelitian. Dalam penelitian ini validitas diketahui melalui data hasil penelitian pada tabel 1 .

TABEL I

RINGKASAN HASIL VALIDITAS INSTRUMEN PENELITIAN

\begin{tabular}{|l|l|l|l|}
\hline No & Variabel & Jumlah Item & $\begin{array}{l}\text { Jumlah Item } \\
\text { Gugur }\end{array}$ \\
\hline 1 & $\begin{array}{l}\text { Persepsi Siswa } \\
\text { tentang Model } \\
\text { Pembelajaran } \\
\text { Kooperatif STAD }\end{array}$ & 20 & 0 \\
\hline 2 & $\begin{array}{l}\text { Pemanfaatan Sumber } \\
\text { Belajar }\end{array}$ & 20 & 0 \\
\hline
\end{tabular}

Berdasarkan hasil validitas, maka dapat diketahui bahwa persepsi siswa tentang model pembelajaran kooperatif STAD tidak ada item yang gugur. Demikian pula dengan pemanfaatan sumber belajar. Dengan demikian item pada tiap variabel dapat digunakan untuk penelitian.

E. Reliabilitas Instrumen

Pengujian reliabilitas dengan metode Alpha Cronbach menggunakan bantuan software statistik SPSS 18 for Windows. Suatu variabel dikatakan reliabel jika memberikan nilai Alpha Cronbach $>0,70$ [12]. Dalam penelitian ini validitas diketahui melalui data hasil penelitian pada tabel 2 .

TABEL 2

RINGKASAN HASIL RELIABILITAS INSTRUMEN PENELITIAN

\begin{tabular}{|l|l|l|l|}
\hline No & Variabel & $\begin{array}{l}\text { Koef } \\
\text { Alpha }\end{array}$ & $\begin{array}{l}\text { Tingkat } \\
\text { Keandalan }\end{array}$ \\
\hline 1 & $\begin{array}{l}\text { Persepsi Siswa tentang } \\
\text { Model Pembelajaran } \\
\text { Kooperatif STAD }\end{array}$ & 0,901 & Baik \\
\hline 2 & $\begin{array}{l}\text { Pemanfaatan Sumber } \\
\text { Belajar }\end{array}$ & 0,906 & Baik \\
\hline
\end{tabular}

Berdasarkan hasil reliabilitas instrumen pada kelas XI jurusan Teknik Instalasi Tenaga Listrik di SMK Negeri 1 Sedayu, diperoleh hasil perhitungan reliabilitas persepsi siswa tentang model pembelajaran kooperatif STAD (X1) sebesar 0,901 dan pemanfaatan sumber belajar (X2) sebesar 0,906. Hal ini menunjukkan bahwa instrumen mempunyai tingkat keterandalan yang baik dan memenuhi syarat sebagai alat pengumpulan data penelitian.

\section{F. Uji Prasarat Analisis}

Uji normalitas dilakukan dengan menggunakan Kolmogorov-Smirnov dengan SPSS 18 for Windows pada taraf signifikansi 5\%. Skor berdistribusi normal jika nilai Sig. Kolomogorov-Smirnov lebih besar dari 0,05 dan sebaliknya apabila nilai Sig. Kolomogorov-Smirnov kurang dari 0,05 skor dikatakan tidak berdistribusi normal atau berdistribusi bebas.

Uji linearitas dilakukan untuk mengetahui apakah masing-masing variabel bebas dengan variabel terikat memiliki hubungan linier atau tidak. Uji linieritas dengan menggunakan bantuan software statistik SPSS 18 for Windows. Setelah diketahui harga Fhitung kemudian dikonsultasikan dengan harga Ftabel pada taraf signifikansi 5\%. Kriterianya apabila harga Fhitung lebih kecil atau sama dengan Ftabel pada taraf signifikansi $5 \%$ maka hubungan antara variabel bebas dikatakan linier. Sebaliknya, apabila Fhitung lebih besar dari pada Ftabel, maka hubungan variabel bebas terhadap variabel terikat tidak linier. Hubungan antara variabel dikatakan linear apabila nilai signifikansi Deviation from linearity $>$ alpha yang ditetapkan (misal 5\%)..

Uji multikolinearitas bertujuan untuk menguji apakah model regresi ditemukan adanya korelasi antar variabel bebas. Uji multikolinearitas dilakukan dengan melihat nilai TOL (Tolerance) dan VIF (Variance Inflantion Factor), jika $\alpha=0.05$ maka batas 
$\mathrm{VIF}=10$. Jika $\mathrm{VIF}<10$ dan TOL $>0.10$ maka tidak terjadi multikolinearitas. Penelitian yang baik adalah jika tidak terjadi multikolinearitas yaitu tidak ada korelasi antar variable bebas.

\section{G. Uji Hipotesis}

Analisis regresi linier sederhana didasarkan pada hubungan fungsional ataupun kausal satu variabel independen dengan satu variabel dependen. Analisis regresi linear sederhana digunakan untuk mengetahui pengaruh persepsi siswa tentang model pembelajaran kooperatif STAD terhadap hasil belajar (hipotesis 1), dan pemanfaatan sumber belajar terhadap hasil belajar (hipotesis 2).Analisis regresi linier ganda didasarkan pada hubungan simultan variabel independen dengan satu variabel dependen.Teknik analisis regresi linear ganda digunakan untuk mengetahui pengaruh persepsi siswa tentang model pembelajaran kooperatif STAD (X1) dan pemanfaatan sumber belajar (X2) secara bersama-sama terhadap variabel hasil belajar (Y)

\section{HASIL PENELITIAN}

\section{A. Deskripsi Data}

Data penelitian tentang persepsi siswa tentang model pembelajaran kooperatif STAD dan pemanfaatan sumber belajar siswa kelas XI program keahlian Teknik Instalasi Tenaga Listrik di SMK Negeri 1 Sedayu Yogyakarta ini, diperoleh melalui angket/kuisioner. Sedangkan data hasil belajar siswa kelas XI program keahlian Teknik Instalasi Tenaga Listrik di SMKN 1 Sedayu diperoleh melalui dokumentasi.

Responden dalam penelitian diambil dari kelas XI program keahlian Teknik Instalasi Tenaga Listrik (TITL) di SMK Negeri 1 Sedayu Yogyakarta yang berjumlah 105 siswa. Data penelitian terdiri dari dua variabel bebas Persepsi Siswa tentang Model Pembelajaran Kooperatif STAD (X1), dan Pemanfaatan Sumber Belajar (X2) serta satu variabel terikat yaitu Hasil Belajar $(\mathrm{Y})$.

Deskripsi data yang disajikan dalam penelitian ini meliputi harga Mean (M), Median (Me), Modus (Mo), dan Standart Deviasi (SD), serta disajikan tabel distribusi frekuensi untuk kecenderungan dari masing-masing variabel. Analisis data di dalam penelitian ini menggunakan software SPSS 18 for Windows.

\section{Persepsi Siswa Tentang Model Pembelajaran Kooperatif STAD:}

Data variabel persepsi siswa tentang model pembelajaran kooperatif STAD diperoleh dari instrumen kuisioner/angket dengan 20 butir pertanyaan dan jumlah responden 105 siswa. Berdasarkan variabel persepsi siswa tentang model pembelajaran kooperatif STAD yang dianalisis menggunakan software SPSS 18 for windows, diperoleh skor tertinggi 80 dan skor terendah 52, sehingga range 28. Nilai mean 68,17; median 69, dan modus 73 serta standart deviasi 7,007. Langkah selanjutnya yang dilakukan yaitu membuat tabel kecenderungan skor variabel persepsi siswa tentang model pembelajaran kooperatif STAD. Tabel kecenderungan digunakan untuk mengetahui antara rentang skor dan jumlah responden yang masuk pada tingkatan tinggi, cukup, rendah kurang. Perhitungan pada lampiran adalah seperti berikut mean ideal (Mi) sebesar 50 dan standar deviasi (Sdi) sebesar 10, sedangkan skor tinggi ideal adalah sebesar 80 dan skor terendah ideal adalah 20 . Kecenderungan skor variabel persepsi siswa tentang model pembelajaran kooperatif STAD diketahui melalui tabel 3.

TABEL 3

KECENDERUNGAN SKOR VARIABEL PERSEPSI SISWA TENTANG MODEL PEMBELAJARAN KOOPERATIF STAD

\begin{tabular}{|l|l|l|l|l|}
\hline No & $\begin{array}{l}\text { Rentang } \\
\text { Skor }\end{array}$ & Kategori & Jumlah & Frekuensi (\%) \\
\hline 1 & $20<48,5$ & Rendah & 3 & 2,86 \\
\hline 2 & $48,5<50$ & Kurang & 5 & 4,76 \\
\hline 3 & $50<65$ & Sedang & 33 & 31,43 \\
\hline 4 & $65<80$ & Tinggi & 64 & 60,95 \\
\hline \multicolumn{2}{|l|}{ Jumlah } & 105 & 100 \\
\hline
\end{tabular}

Berdasarkan tabel 3, diketahui persepsi siswa tentang model pembelajaran kooperatif STAD pada kategori rendah sebanyak 3 siswa (2,86\%), kategori kurang sebanyak 5 siswa $(4,76 \%)$, kategori sedang sebanyak 33 siswa $(31,43 \%)$, dan yang masuk pada kategori tinggi sebanyak 64 siswa (60,95\%). Histrogram tabel model pembelajaran kooperatif STAD adalah dapat dilihat pada Gambar 1.

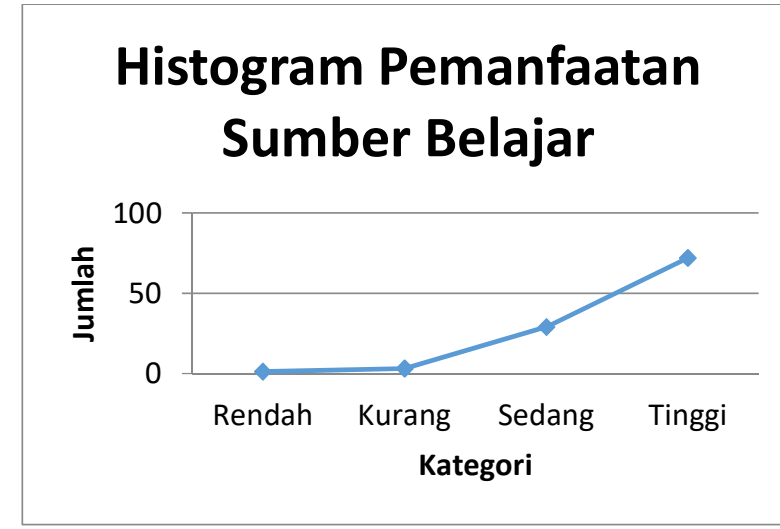

Gambar 1. Histogram Frekuensi Pemanfaatan Sumber Belajar

Berdasarkan nilai mean, dapat ditegaskan bahwa kecenderungan pemanfaatan sumber belajar termasuk dalam kategori sangat baik. Diketegorikan sangat baik karena berdasarkan data pengisian angket yang dilakukan oleh siswa, sehingga kejujuran siswa dalam pengisian angket belum terjamin.

\section{Pemanfaatan Sumber Belajar}

Data variabel pemanfaatan sumber belajar diperoleh dari instrumen kuisioner/angket dengan 20 butir pertanyaan dan jumlah responden 105 siswa. Berdasarkan variabel pemanfaatan sumber belajar (X2) yang dianalisis menggunakan software SPSS 18 for windows, maka diperoleh skor tertinggi 80 dan skor terendah 47 , sehingga range 33 . Nilai mean 67,95 ; median 68 , dan modus 80 serta standart deviasi 7,92. Langkah selanjutnya yang dilakukan yaitu membuat tabel kecenderungan skor variabel pemanfaatan sumber belajar. Tabel kecenderungan digunakan untuk mengetahui antara rentang skor dan jumlah responden yang 
masuk pada tingkatan tinggi, cukup, rendah kurang. Perhitungan pada lampiran adalah seperti berikut mean ideal (Mi) sebesar 50 dan standar deviasi (Sdi) sebesar 10, sedangkan skor tinggi ideal adalah sebesar 80 dan skor terendah ideal adalah 20. Kecenderungan skor variabel pemanfaatan sumber belajar diketahui melalui tabel 4.

TABEL 4.

KECENDERUNGAN SKOR VARIABEL PEMANFAATAN SUMBER BELAJAR

\begin{tabular}{|l|l|l|l|l|}
\hline No & $\begin{array}{l}\text { Rentang } \\
\text { Skor }\end{array}$ & Kategori & Jumlah & Frekuensi (\%) \\
\hline 1 & $20<48,5$ & Rendah & 1 & 0,95 \\
\hline 2 & $48,5<50$ & Kurang & 3 & 2,86 \\
\hline 3 & $50<65$ & Sedang & 29 & 27,62 \\
\hline 4 & $65<80$ & Tinggi & 72 & 68,57 \\
\hline \multicolumn{2}{|l}{ Jumlah } & 105 & 100 \\
\hline
\end{tabular}

Berdasarkan tabel 4, diketahui pemanfaatan sumber belajar pada kategori rendah sebanyak 1 siswa $(0,95 \%)$, kategori kurang sebanyak 3 siswa (2,86\%), kategori sedang sebanyak 29 siswa $(27,62 \%)$, dan yang masuk pada kategori tinggi sebanyak 72 siswa $(68,57 \%)$. Histrogram tabel kecenderungan pada pemanfaatan sumber belajar dapat dilihat pada Gambar 2.

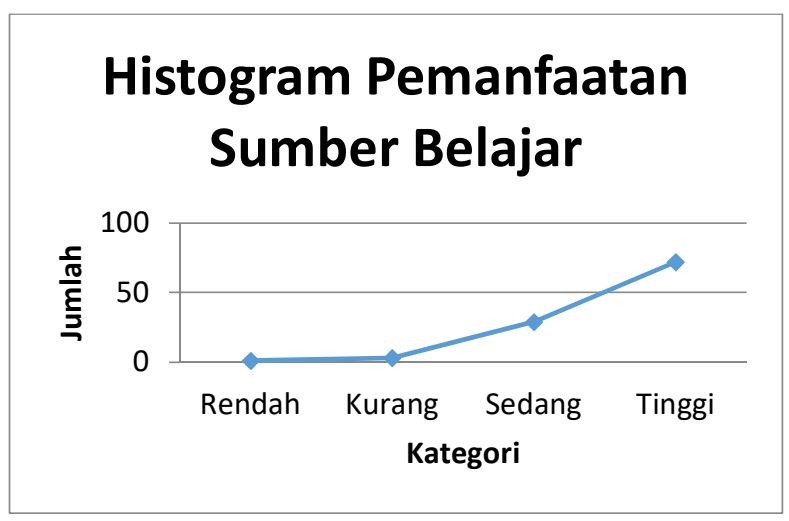

Gambar 2. Histogram Pemanfaatan Sumber Belajar

Berdasarkan nilai mean, dapat ditegaskan bahwa kecenderungan pemanfaatan sumber belajar termasuk dalam kategori sangat baik. Diketegorikan sangat baik karena berdasarkan data pengisian angket yang dilakukan oleh siswa, sehingga kejujuran siswa dalam pengisian angket belum terjamin.

\section{Hasil Belajar :}

Data variabel hasil belajar diperoleh dari dokumentasi nilai ulangan harian dari jumlah responden 105 siswa.. Berdasarkan variabel hasil belajar (Y2) yang dianalisis menggunakan software SPSS 18 for windows, maka diperoleh skor tertinggi 85 dan skor terendah 60 , sehingga range 25 . Nilai mean 66,58; median 65, dan modus 60 serta standart deviasi 5,42.
Distribusi frekuensi variable hasil belajar ditunjukkan melalui tabel 5.

TABEL 5.

DISTRIBUSI FREKUENSI VARIABEL HASIL BELAJAR

\begin{tabular}{|c|c|c|c|}
\hline No & Interval & Frekuensi & Presentase (\%) \\
\hline 1 & $60-<63$ & 29 & 27,61 \\
\hline 2 & $63-<66$ & 27 & 25,71 \\
\hline 3 & $66-<72$ & 7 & 6,67 \\
\hline 4 & $69-<72$ & 24 & 22,86 \\
\hline 5 & $72-<75$ & 4 & 3,81 \\
\hline 6 & $75-<78$ & 13 & 12,38 \\
\hline 7 & $78-<81$ & 0 & 0 \\
\hline 8 & $81-<84$ & 1 & 0,95 \\
\hline \multicolumn{2}{|c|}{ Jumlah } & 105 & $100 \%$ \\
\hline
\end{tabular}

Berdasarkan tabel distribusi frekuensi variabel hasil belajar, frekuensi tertinggi pada kelas interval nomer 1 yang mempunyai rentang 60-63 dengan jumlah sebanyak 29 siswa Histrogram tabel distribusi frekuensi hasil belajar dapat dilihat pada Gambar 3.

\section{Distribusi Frekuensi Hasil Belajar}

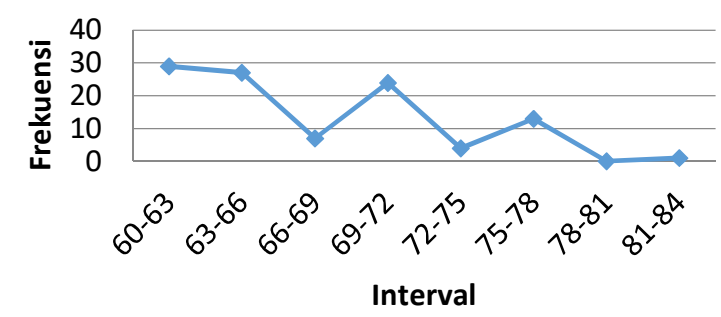

Gambar 3. Histogram Distribusi Frekuensi Hasil Belajar

Frekuensi hasil belajar dapat dilihat pada tabel dan diagram batang yaitu pada interval $60-<63$ sebanyak 29 siswa, interval $63-<66$ sebanyak 27 siswa, interval $66-<69$ sebanyak 7 siswa, interval $69-<72$ sebanyak 24 siswa, interval $72-<75$ sebanyak 4 siswa, interval 75- $<78$ sebanyak 13 siswa, interval 78 $<81$ sebanyak 0 siswa dan interval $81-<84$ sebanyak 1 siswa.

Nilai KKM yang harus dicapai siswa adalah 70. Dari 105 siswa yang telah mencapai KKM dapat diketahui ada 42 siswa yang telah mencapai nilai KKM atau sebanyak 40\%, dan 63 siswa belum mencapai nilai KKM atau sebanyak $60 \%$.

B. Uji Prasarat Analisis

Uji prasarat analisis menggunakan uji normalitas, uji linieritas, Uji multikolinieritas.

1. Analisis Uji Normalitas: 
Pengujian normalitas dilakukan untuk mengetahui data dari tiap variabel distribusinya normal atau tidak. Penelitian ini, teknik analisis yang dipakai untuk menguji normalitas data adalah teknik analisis one sample kolmogorov-smirnov test (K-S). Distibusi dianggap normal jika $\mathrm{p}>0,05$. Analisis data ini dilakukan dengan bantuan komputer program SPSS 18 for windows. Hasil uji normalitas ditunjukkan melalui tabel 6.

TABEL 6.

RANGKUMAN HASIL UJI NORMALITAS

\begin{tabular}{|c|l|c|c|l|}
\hline No & \multicolumn{1}{|c|}{ Variabel } & $(\mathrm{p})$ & Kondisi & Keterangan \\
\hline 1 & $\begin{array}{l}\text { Persepsi Siswa } \\
\text { tentang Model } \\
\text { Pembelajaran } \\
\text { Kooperatif STAD }\end{array}$ & 1,389 & $\mathrm{P}>0,05$ & $\begin{array}{l}\text { Distribusi } \\
\text { Normal }\end{array}$ \\
\hline 2 & $\begin{array}{l}\text { Pemanfaatan } \\
\text { Sumber Belajar }\end{array}$ & 0,820 & $\mathrm{P}>0,05$ & $\begin{array}{l}\text { Distribusi } \\
\text { Normal }\end{array}$ \\
\hline 3 & Hasil Belajar & 1,678 & $\mathrm{P}>0,05$ & $\begin{array}{l}\text { Distribusi } \\
\text { Normal }\end{array}$ \\
\hline
\end{tabular}

Dari tabel 6 terlihat bahwa semua variabel yang ada pada penelitian ini berdistribusi normal.

2. Analisis Uji Linieritas:

Uji linearitas digunakan untuk mengetahui adanya hubungan antara variabel bebas (independen) dengan variabel terikat (dependen) apakah berbentuk linear atau tidak. Hasil uji linieritas ditunjukkan melalui tabel 7.

TABEL 7.

RANGKUMAN HASIL UJI LINIERITAS

\begin{tabular}{|c|l|c|l|l|}
\hline No & \multicolumn{1}{|c|}{ Variabel } & $\begin{array}{c}\text { Nilai } \\
\mathrm{F}\end{array}$ & Signifikasi & Keterangan \\
\hline 1 & $\begin{array}{l}\text { Persepsi Siswa } \\
\text { tentang Model } \\
\text { Pembelajaran } \\
\text { Kooperatif STAD }\end{array}$ & 1,223 & 0,253 & Linier \\
\hline 2 & $\begin{array}{l}\text { Pemanfaatan } \\
\text { Sumber Belajar }\end{array}$ & 0,483 & 0,983 & Linier \\
\hline
\end{tabular}

Hasil analisis pada variabel persepsi siswa tentang model pembelajaran kooperatif STAD menunjukkan nilai $\mathrm{F}$ sebesar 1,223 dan nilai signifikansi 0,253 hal ini menunjukan bahwa signifikansi $(0,253)>\mathrm{p}(0,05)$. Dengan demikian hasilnya adalah model regresi linear.

Hasil analisis pada variabel pemanfaatan sumber belajar menunjukan nilai $F$ sebesar 0,483 dan nilai signifikansi 0,983 hal ini menunjukan bahwa signifikansi $(0,983)>p(0,05)$. Dengan demikian hasilnya adalah model regresi linear.

3. Analisis Multikolineritas:

Uji multikolineritas ini dilakukan mengetahui ada tidaknya suatu hubungan (korelasi) yang signifikan antar variabel bebas. Rangkuman hasil uji multikolineritas dapat dilihat pada tabel 8 .
TABEL 8.

\section{RANGKUMAN HASIL UJI MULTIKOLINERITAS}

\begin{tabular}{|c|c|c|c|c|}
\hline No & Variabel & VIF & Signifikasi & Simpulan \\
\hline 1 & $\begin{array}{l}\text { Persepsi } \\
\text { Siswa tentang } \\
\text { Model } \\
\text { Pembelajaran } \\
\text { Kooperatif } \\
\text { STAD }\end{array}$ & 2,717 & 5 & $\begin{array}{lr}\text { Tidak terjadi } \\
\text { Multikolineritas }\end{array}$ \\
\hline 2 & $\begin{array}{l}\text { Pemanfaatan } \\
\text { Sumber } \\
\text { Belajar }\end{array}$ & 2,717 & 5 & $\begin{array}{l}\text { Tidak terjadi } \\
\text { Multikolineritas }\end{array}$ \\
\hline
\end{tabular}

\section{Uji Hipotesis}

Hipotesis adalah jawaban sementara atas permasalahan yang dirumuskan. Maka jawaban sementara ini diuji kebenarannya secara empirik dengan menggunakan teknik regresi sederhana untuk hipotesis pertama dan kedua, sedangkan untuk menguji hipotesis ketiga digunakan teknik analisis regresi ganda. Penjelasan tentang hasil pengujian hipotesis penelitian ini adalah sebagai berikut:

1. Uji Hipotesisi Pertama (X1-Y) Persepsi Siswa tentang Model Pembelajaran Kooperatif STAD terhadap Hasil Belajar:

Hipotesis yang diajukan dalam penelitian ini adalah terdapat pengaruh dan signifikan Persepsi Siswa tentang Model Pembelajaran Kooperatif STAD terhadap Hasil Belajar siswa kelas XI SMK Negeri 1 Sedayu. Untuk menguji hipotesis tersebut digunakan analisis regresi sederhana.

Berdasarkan data penelitian yang diolah menggunakan software SPSS 18 for Windows,ringkasan hasil analisis regresi sederhana dapat dilihat pada tabel 9.

TABEL 9.

RANGKUMAN HASIL UJI REGRESI LINIER MODEL PEMBELAJARAN KOOPERATIF STAD TERHADAP HASIL BELAJAR

\begin{tabular}{|l|l|l|l|l|}
\hline Sumber & Koef & $\mathrm{R}^{2}$ & t-hitung & $\mathrm{t}$-tabel \\
\hline Konstanta & 29,798 & & & \\
$\begin{array}{l}\text { Persepsi Siswa } \\
\text { tentang Model } \\
\begin{array}{l}\text { Pembelajaran } \\
\text { Kooperatif } \\
\text { STAD }\end{array}\end{array}$ & 0,540 & 0,48 & 9,874 & 1,983 \\
\hline
\end{tabular}

Pengujian signifikansi bertujuan untuk mengetahui signifikansi pengaruh persepsi siswa tentang model pembelajaran kooperatif STAD (X1) terhadap hasil belajar (Y). Hipotesis yang di uji adalah terdapat pengaruh yang positif persepsi siswa tentang model pembelajaran kooperatif STAD terhadap hasil belajar siswa kelas XI Program Keahlian Teknik Instalasi Tenaga Listrik SMK Negeri 1 Sedayu. Uji signifikansi menggunakan uji $\mathrm{T}$. Berdasarkan hasil uji T diperoleh nilai t-hitung sebesar 9,874. Jika dibandingkan dengan nilai t-tabel sebesar 1,983 pada taraf signifikansi $5 \%$ maka nilai t-hitung $>\mathrm{t}$-tabel sehingga hipotesis 
pertama diterima. Hal ini berarti bahwa Ho ditolak dan Ha diterima sehingga terdapat pengaruh positif dan signifikan persepsi siswa tentang model pembelajaran koopertif STAD terhadap hasil belajar siswa kelas XI program keahlian TITL di SMK Negeri 1 Sedayu

2. Hipotesisi Kedua (X2-Y) Pemanfaatan Sumber Belajar terhadap Hasil Belajar:

Hipotesis yang diajukan dalam penelitian ini adalah terdapat pengaruh dan signifikan pemanfaatan sumber belajar terhadap hasil belajar siswa kelas XI di SMK Negeri 1 Sedayu. Untuk menguji hipotesis tersebut digunakan analisis regresi sederhana.

Berdasarkan data penelitian yang diolah menggunakan software SPSS 18 for Windows,ringkasan hasil uji regresi linier pemanfaatan sumber belajar terhadap hasil belajar dapat dilihat pada tabel 10 .

TABEL 10.

RANGKUMAN HASIL UJI REGRESI LINIER PEMANFAATAN SUMBER BELAJAR TERHADAP HASIL BELAJAR

\begin{tabular}{|l|l|l|l|l|}
\hline Sumber & Koef & $\mathrm{R}^{2}$ & t-hitung & t-tabel \\
\hline Konstanta & 41,637 & & & \\
$\begin{array}{l}\text { Pemanfaatan } \\
\text { Sumber Belajar }\end{array}$ & 0,367 & 0,28 & 6,443 & 1,983 \\
\hline
\end{tabular}

Pengujian signifikansi bertujuan untuk mengetahui signifikansi pengaruh pemanfaatan sumber belajar (X2) terhadap hasil belajar (Y). Hipotesis yang di uji adalah terdapat pengaruh yang positif pemanfaatan sumber belajar terhadap hasil belajar siswa kelas XI Kompetensi Keahlian Teknik Instalasi Tenaga Listrik (TITL) di SMK Negeri 1 Sedayu. Uji signifikansi menggunakan uji T. Berdasarkan hasil uji T diperoleh nilai t-hitung sebesar 6,443. Jika dibandingkan dengan nilai t-tabel sebesar 1,983 pada taraf signifikansi 5\% maka nilai t-hitung $>$ t-tabel sehingga hipotesis kedua diterima. Hal ini berarti bahwa Ho ditolak dan Ha diterima sehingga terdapat pengaruh positif pemanfaatan sumber belajar terhadap hasil belajar siswa kelas XI Program Keahlian Teknik Instalasi Tenaga Listrik SMK Negeri 1 Sedayu Yogyakarta.

3. Uji Hipotesisi Ketiga (X1, X2-Y) Persepsi Siswa tentang Model Pembelajaran Kooperatif STAD dan Pemanfaatan Sumber Belajar terhadap Hasil Belajar :

Hipotesis yang diajukan dalam penelitian ini adalah terdapat pengaruh dan signifikan antara persepsi siswa tentang model pembelajaran kooperatif STAD dan pemanfaatan sumber belajar terhadap hasil belajar siswa kelas XI SMK Negeri 1 Sedayu. Untuk menguji hipotesis tersebut digunakan analisis regresi linear ganda.

Berdasarkan data penelitian yang diolah menggunakan software SPSS 18 for Windows,ringkasan hasil analisis regresi sederhana dapat dilihat pada tabel 11 .
TABEL 11.

RANGKUMAN HASIL UJI REGRESI LINIER GANDA DARI PERSEPSI SISWA TENTANG MODEL PEMBELAJARAN KOOPERATIF STAD DAN PEMANFAATAN SUMBER BELAJAR TERHADAP HASIL BELAJAR

\begin{tabular}{|l|l|l|l|l|}
\hline Sumber & Koef & $\mathrm{R}^{2}$ & F-hitung & F-tabel \\
\hline Konstanta & 30,028 & & & \\
$\begin{array}{l}\text { Persepsi Siswa } \\
\text { tentang Model } \\
\text { Pembelajaran } \\
\text { Kooperatif } \\
\text { STAD }\end{array}$ & 0,570 & 0,48 & 48,45 & 3,085 \\
$\begin{array}{l}\text { Pemanfaatan } \\
\text { Sumber Belajar }\end{array}$ & $-0,034$ & & & \\
\hline
\end{tabular}

Pengujian signifikansi bertujuan untuk mengetahui signifikansi pengaruh persepsi siswa tentang model pembelajaran kooperatif STAD (X1) dan Pemanfaatan sumber belajar (X2) terhadap hasil belajar (Y). Hipotesis yang diuji adalah terdapat pengaruh yang positif persepsi siswa tentang model pembelajaran kooperatif STAD dan pemanfaatan sumber belajar secara bersama-sama terhadap hasil belajar siswa kelas XI program keahlian Teknik Instalasi Tenaga Listrik di SMK Negeri 1 Sedayu. Uji signifikansi menggunakan uji F.

Berdasarkan hasil uji $\mathrm{F}$ diperoleh nilai F-hitung sebesar 48,452. Jika dibandingkan dengan nilai F-tabel sebesar 3,085 pada taraf signifikansi $5 \%$ maka nilai F-hitung $>$ F-tabel sehingga hipotesis ketiga diterima. Hal ini berarti bahwa Ho ditolak dan $\mathrm{Ha}$ diterima sehingga terdapat pengaruh persepsi siswa tentang model pembelajaran kooperatif STAD dan pemanfaatan sumber belajar terhadap hasil belajar siswa kelas XI program keahlian Teknik Instalasi Tenaga Listrik di SMK N.1 Sedayu.

\section{Pembahasan}

Penelitian ini bertujuan untuk menguji pengaruh model pembelajaran kooperatif STAD (X1) dan pemanfaatan sumber belajar (X2) terhadap hasil belajar siswa kelas XI Program Keahlian Teknik Instalasi Tenaga Listrik di SMK Negeri 1 Sedayu. Berdasarkan data penelitian yang dianalisis dengan bantuan SPSS 18 for windows, maka dilakukan pembahasan tentang hasil penelitian sebagai berikut.

1. Pengaruh Persepsi Siswa Tentang Model Pembelajaran Kooperatif STAD Terhadap Hasil Belajar

Hasil penelitian menunjukkan terdapat pengaruh yang positif dan signifikan persepsi siswa tentang model pembelajaran kooperatif STAD terhadap hasil belajar siswa kelas XI program keahlian Teknik Instalasi Tenaga Listrik di SMK Negeri 1 Sedayu yang ditunjukan melalui uji regresi sederhana $(\mathrm{rx} 1, \mathrm{y})$ dengan hasil koefisien regresi (rx1y) sebesar 0,697 dan koefisien determinan ( $2 x 1 y)$ atau besarnya sumbangan pengaruh persepsi siswa tentang model pembelajaran kooperatif STAD terhadap hasil belajar tersebut adalah 0,486 atau sebesar $48,6 \%$, selanjutnya dilanjutkan 
uji keberhasilan terhadap koefisien regresi dengan menggunakan uji T pada taraf signifikansi 5\%. Hasil perhitungan diperoleh harga t-hitung sebesar 9,874 dan t-tabel sebesar 1,983. Harga t-hitung lebih besar dari t-tabel sehingga dapat disimpulkan bahwa persepsi siswa tentang model pembelajaran kooperatif STAD memberikan pengaruh yang positif dan signifikan terhadap hasil belajar siswa kelas XI program keahlian Teknik Instalasi Tenaga Listrik di SMK Negeri 1 Sedayu.

2. Pengaruh Pemnafaatan Sumber Belajar Terhadap Hasil Belajar:

Hasil perhitungan kedua dari penelitian ini adalah terdapat pengaruh yang positif dan signifikan pemanfaatan sumber belajar (X2) terhadap hasil belajar siswa kelas XI program keahlian Teknik Instalasi Tenaga Listrik di SMK Negeri 1 Sedayu. Hasil uji regresi sederhana (rx2y) menunjukkan bahwa koefisien regresi (rx2y) adalah sebesar 0,536 dan koefisien determinasi $(\mathrm{r} 2 \mathrm{x} 2 \mathrm{y})$ atau besarnya sumbangan pengaruh pemanfaatan sumber belajar terhadap hasil belajar tersebut adalah 0,287 atau sebesar $28,7 \%$, selanjutnya dilakukan uji keberartian terhadap koefisien regresi dengan menggunakan statistik uji $\mathrm{T}$ pada taraf signifikan $5 \%$. Hasil perhitungan diperoleh harga t-hitung sebesar 6,443 dan t-tabel sebesar 1,983. Harga t-hitung lebih besar dari t-tabel, sehingga dapat disimpulkan bahwa pemanfaatan sumber belajar memberikan pengaruh positif dan signifikan terhadap hasil belajar siswa kelas XI program keahlian Teknik Instalasi Tenaga Listrik di SMK Negeri 1 Sedayu.

3. Pengaruh Persepsi Siswa Tentang Model Pembelajaran Kooperatif STAD Dan Pemnafaatan Sumber Belajar Terhadap Hasil Belajar:

Hasil penelitian ini menunjukkan bahwa terdapat pengaruh positif dan signifikan persepsi siswa tentang model pembelajaran kooperatif STAD (X1) dan pemanfatan sumber belajar (X2) secara bersama terhadap hasil belajar siswa (Y) melalui analisis regresi ganda yang kemudian diperoleh koefisien regresi ganda $(\mathrm{R} 1,2)$ sebesar 0,698 dan koefisien determinasi $(\mathrm{R} 21,2)$ sebesar 0,487 yang berarti persepsi siswa tentang model pembelajaran kooperatif STAD dan pemanfaatan sumber belajar secara bersama-sama berpengaruh dengan hasil belajar siswa sebesar 48,7\%. Selanjutnya dilakukan uji keberartian regresi ganda dengan uji $\mathrm{F}$ pada taraf signifikansi 5\%. Hasil perhitungan diperoleh f-hitung sebesar 48,452 dan f-tabel sebesar 3,085. Hasil f-hitung $>$ f-tabel hal ini menunjukkan bahwa terdapat pengaruh yang positif dan signifikan persepsi siswa tentang model pembelajaran kooperatif STAD dan pemanfaatan sumber belajar bersama-sama terhadap hasil belajar siswa kelas XI program keahlian Teknik Instalasi Tenaga Listrik di SMK Negeri 1 Sedayu.

\section{KESIMPULAN}

Persepsi siswa tentang model pembelajaran kooperatif STAD siswa kelas XI Program Keahlian TITL di SMK Negeri 1
Sedayu secara umum tergolong sangat baik, Pemanfaatan sumber belajar siswa kelas XI Program Keahlian TITL di SMK Negeri 1 Sedayu secara umum tergolong sangat baik, dan Hasil belajar siswa kelas XI Program Keahlian TITL di SMK Negeri 1 Sedayu yang telah mencapai KKM sebanyak $40 \%$ dan siswa belum mencapai KKM sebanyak $60 \%$. Nilai rata-rata siswa adalah 66,58 sedangkan nilai tertinggi 85 dan nilai terendah 60 .

\section{DAFTAR PUSTAKA}

[1] Slavin, Cooperative Learning: Teori Riset, Dan Praktik. (Terjemahan oleh: Nurulita) Bandung: Nusamedia, 2014.

[2] Rusman, Model-Model Pembelajaran Bandung: Mulia Mandiri Press, 2016..

[3] A. Suprijono, Cooperative Learning. Yogyakarta: Pustaka Pelajar, 2018.

[4] Slameto, Belajar dan Faktor-Faktor Yang Mempengaruhinya . Jakarta: Rineka Cipta, 2014.

[5] B. Walgito, Media Pembelajaran . Jakarta: Rajawali Press, 2018.

[6] Y. Hadi,Menyemai Benih Teknologi Pendidikan. Jakarta: Prenda Nedia.

[7] Rahmadi. Strategi Belajar Mengajar Bandung: Pustaka Setia, 2014.

[8] Sudjana, Penilaian Pencapaian Hasil Belajar . Yogyakarta: FPTK IKIP, 2018.

[9] Zaenal, Komunikasi Pembelajaran. Surabaya: University Press, 2015.

[10] itriana. Penilaian Pencapaian Hasil Belajar Di Sekolah. Yogyakarta: Kanisius, 2017.

[11] Hasan, Pendidikan Ilmu Sosial . Jakarta: Depdikbud, 2018.

[12] Masidjo, Model-Model Mengajar. Bandung: CV. Diponegoro, 2017. 